\title{
Malgorzata Wachowska*
}

Uniwersytet Wrocławski

\section{KIERUNKI POAKCESYJNEJ EMIGRACJI POLSKICH WYNALAZCÓW}

\begin{abstract}
Streszczenie
Celem artykułu jest ustalenie wielkości oraz geograficznych kierunków emigracji polskich wynalazców w latach 2004-2012. Analiza zgłoszeń patentowych dokonywanych w latach 2004-2012 w ramach procedury międzynarodowej przez rezydentów z Europy, Ameryki Północnej, Australii oraz największych gospodarek Azji i Ameryki Południowej wykazała, że w latach 2004-2012, łącznie w 46 państwach objętych analizą, przebywało 962 wynalazców pochodzenia polskiego. Głównym kierunkiem ich migracji była Europa (głównie Niemcy, Wielka Brytania, Szwajcaria i Holandia), w której przebywało łącznie 581 twórców rozwiązań technicznych, oraz Ameryka Północna (głównie Stany Zjednoczone), która przyciągnęła 363 polskich wynalazców. W Azji, Ameryce Południowej i Australii obecność polskich wynalazców była incydentalna.
\end{abstract}

Słowa kluczowe: migracja kapitału ludzkiego, wynalazcy, aplikacje patentowe PCT, Polska

\footnotetext{
*Adres e-mail: malgorzata.wachowska@uwr.edu.pl.
} 


\section{Wprowadzenie}

Począwszy od lat 90. XX wieku można zaobserwować wzrost w globalnych przepływach wysoko wykształconej migracji, i to zarówno w ujęciu absolutnym, jak również w odniesieniu do całkowitej migracji (Freeman, 2010; Docquier, Rapoport, 2012). Kraje, które w największym stopniu doświadczają tego zjawiska, są zazwyczaj duże, o dużej liczbie ludności, przy czym niekoniecznie o niskim stopniu rozwoju. Wśród państw europejskich, z których pochodzą największe zasoby wysoko wykształconych migrantów, wskazuje się Wielką Brytanię, Niemcy, Polskę, Rosję, Francję, Rumunię, Ukrainę i Włochy, wśród państw z obu Ameryk - Meksyk, Stany Zjednoczone i Kanadę, zaś pośród gospodarek azjatyckich, jednocześnie będących na szczycie światowej listy państw pochodzenia wysoko wykształconych emigrantów, znajdują się Indie, Chiny i Filipiny (OECD, 2013, 2015).

Niestety nie zawsze kraje, które są największymi dostarczycielami zasobów kapitału ludzkiego, doświadczają jednocześnie największych przyrostów wysoko wykwalifikowanej imigracji, co w naturalny sposób mogłoby rekompensować im tę stratę. Stąd też politycy państw, z których emigruje kapitał ludzki, mobilność pracowników postrzegają jako potencjalne zagrożenie, obawiając się, że wraz z ich odpływem zostaną utracone ich wiedza i umiejętności, co w konsekwencji będzie mieć negatywny wpływ na potencjał do absorpcji i generowania innowacji w kraju. De facto jednak, politycy nie tyle obawiają się odpływu osób wykształconych (chociaż ich również), ile raczej osób wybitnych, o wyjątkowych kwalifikacjach, wnoszących szczególny wkład w zmiany technologiczne zachodzące na świecie.

Ze względu jednak na to, że dane dotyczące migracji są mało precyzyjne i szczegółowe, nie pozwalając na wyodrębnienie spośród mobilnych osób o wysokim kapitale ludzkim tych wyjątkowo twórczych, obawy i lęki polityków potęgują się wraz z nasilającą się emigracją osób wysoko wykwalifikowanych w ogólności, czyli osób z osiągniętym trzecim poziomem edukacji (w Polsce odpowiednik wykształcenia wyższego). Zbiory jednostek zaliczane do poszczególnych poziomów edukacji są jednak bardzo heterogeniczne. Dotyczy to zwłaszcza trzeciego poziomu edukacji, do którego zaliczane są zarówno osoby ze stopniem magistra, doktoranci, jak i doktorzy czy profesorowie, a także laureaci nagrody Nobla.

Wnioskowanie o jakichkolwiek skutkach mobilności wysoko wykształconego kapitału ludzkiego ujmowanego jako całość jest więc obarczone dużym błędem. 
Skupienie się na węższym, bardziej homogenicznym zbiorze wysoko wykwalifikowanych mobilnych jednostek pozwoliłoby na lepsze określenie np. rzeczywistych ewentualnych strat dla kraju macierzystego związanego z odpływem talentów.

Ponieważ silne emocje związane z emigracją młodych, wykształconych osób towarzyszą dyskusjom podejmowanym w krajach, które, tak jak Polska, w 2004 roku przystąpiły do Unii Europejskiej, i które w związku z tym borykają się z odpływem - w szczególności do państw UE - naukowców, inżynierów i wysokiej klasy specjalistów, celem artykułu jest ustalenie wielkości oraz geograficznych kierunków emigracji polskich wynalazców po 2004 roku. Ustalenie, ilu wynalazców decyduje się na opuszczenie własnego kraju oraz tego, jakie są ich docelowe kierunki migracji, jest niejako etapem wstępnym do dalszych badań, które mogłyby się skupić na skutkach tej emigracji dla potencjału innowacyjnego gospodarki źródłowej. Ograniczenie badań jedynie do szczególnego zbioru wysoko wykwalifikowanego kapitału ludzkiego - wynalazców - pozwoliłoby zaś sformułować bardziej precyzyjne wnioski co do rzeczywistych strat dla potencjału innowacyjnego kraju.

W artykule wykorzystano metodę analizy zgłoszeń patentowych, pod kątem narodowości twórców zgłaszanych do ochrony wynalazków dokonywanych w latach 2004-2012 w ramach procedury międzynarodowej, czyli w ramach Układu o Współpracy Patentowej (The Patent Cooperation Treaty: PCT) przez rezydentów z Europy, Ameryki Północnej, Australii oraz największych gospodarek Azji i Ameryki Południowej (łącznie 46 państw). Pozwoliło to na wyodrębnienie tych wniosków patentowych, w przypadku których autorami rozwiązań technicznych są imigranci z Polski i w konsekwencji na ustalenie ich liczby oraz docelowych miejsc pobytu.

Badaniem objęto wyjątkową grupę kapitału ludzkiego, mającą szczególny wkład w zmiany technologiczne zachodzące na świecie, mianowicie twórców wynalazków PCT, pochodzących z Polski. Powszechnie uważa się, że „wynalazki międzynarodowe" są cenniejsze od pozostałych, jako że charakteryzują się wyższym potencjałem komercjalizacyjnym. Wynika to z faktu, że procedura międzynarodowa jest bardziej kosztowna niż krajowa czy regionalna, co sprawia, że decydują się na nią jedynie te jednostki czy podmioty, które same wysoko ocenią potencjał ekonomiczny wynalazku. 


\section{Dane patentowe w badaniu ścieżek migracyjnych wynalazców}

Dane patentowe mogą stanowić cenne źródło informacji na temat ścieżek migracyjnych wynalazców, jako że w dokumentach patentowych odnotowywane jest imię i nazwisko twórcy wynalazku, jego miejsce pobytu w dniu dokonania zgłoszenia i, w niektórych aplikacjach, również jego narodowość. Powyższe dane pozwalają zatem na określenie liczby mobilnych wynalazców, ich państw źródłowych i przyjmujących, a także liczby tworzonych przez nich rozwiązań technicznych.

Niestety trudnością, przed którą stoją badacze, jest jednoznaczne ustalenie narodowości wynalazców w sytuacji, gdy w aplikacji patentowej nie ma podanej takiej informacji. Wówczas autorzy badań, w których podejmowana jest problematyka mobilności wynalazców o narodowości twórcy rozwiązania technicznego wnioskują na podstawie etnicznego pochodzenia jego nazwiska, co w oczywisty sposób sprzyja wielu pomyłkom (Agrawal, Kapur, McHale, 2008; Azoulay, Graff Zivin, Sampat, 2011). Dlatego w badaniu przepływów migracyjnych wynalazców szczególnie cenne są zasoby wiedzy Światowej Organizacji Własności Intelektualnej (World Intellectual Property Organization - WIPO), która opracowała formularz wniosku PCT i administracyjnie obsługuje zgłoszenia w trybie międzynarodowym. Do 2012 roku we wnioskach PCT, jako jedynych, ujawniana była narodowość wynalazcy z racji tego, że istniał wymóg wpisywania wynalazców w polu zgłaszającego. Ponieważ zgłaszający ma obowiązek podać informację o narodowości, w efekcie również wynalazca musiał ujawnić swą narodowość.

Niestety, ze względu na wprowadzone 16 stycznia 2012 roku zmiany w prawie patentowym Stanów Zjednoczonych, jedynie w nielicznych wnioskach PCT zgłaszanych po tym terminie wskazywana jest narodowość twórców wynalazków (Miguelez, Fink, 2013), jako że jedynie nieliczni twórcy wynalazków są dopisywani do zgłaszających. Stany Zjednoczone w ramach Leahy-Smith America Invents Act (AIA) zlikwidowały obowiązek wymieniania wynalazców jako zgłaszających w tych zgłoszeniach PCT, w których Stany Zjednoczone są wskazywane jako tzw. kraj wyznaczony w zgłoszeniu (kraj, w którym zgłaszający rozważa staranie się o ochronę patentową). To do zgłaszającego należy decyzja, czy wynalazców łączyć wraz ze zgłaszającym. W praktyce zdecydowana większość zgłaszających skorzystała z możliwości niewymieniania twórców wynalazków wśród zgłaszających. Zważywszy, że zdecydowana większość „patentów międzynarodowych” swym 
zasięgiem obejmuje Stany Zjednoczone, po roku 2012 zgłoszenia patentowe PCT stają się zdecydowanie mniej przydatne w badaniach nad migracją ludności oraz jej rolą w procesach transferu wiedzy.

Niniejsze badanie, podobnie jak badanie Migueleza i Finka (2013), Breschiego, Lissoniego i Tarasconiego (2014) oraz Breschiego, Lissoniego i Migueleza (2015), czerpie z zasobów wiedzy WIPO dla ustalenia liczby polskich wynalazców na emigracji w latach 2004-2012, co pozwala na pokonanie ograniczeń związanych z danymi po roku 2012. Ponadto, w celu obliczenia wielkości populacji polskich wynalazców na emigracji w poszczególnych latach, w artykule przyjmuje się założenie, że polski wynalazca w określonym roku przebywał na emigracji w określonym kraju nawet wówczas, jeśli nie wynika to $\mathrm{z}$ dokumentacji patentowej (w analizowanym roku nie dokonał żadnego zgłoszenia patentowego), pod warunkiem, że w tym samym kraju w latach wcześniejszych lub późniejszych był aktywny wynalazczo, co wynika $\mathrm{z}$ aplikacji patentowych.

Pomimo swoich wielu zalet, badania migracyjne wykorzystujące dane patentowe, w tym także analizy podjęte w niniejszym artykule, mają swoje ograniczenia. Przede wszystkim, pozwalają jedynie na formułowanie wniosków odnośnie liczby przebywających w danym roku w określonym kraju wynalazców z poszczególnych stron świata, nie pozwalają jednak na jednoznaczne stwierdzenie, w którym roku wynalazca opuścił swój kraj. Dla przykładu, w grupie polskich wynalazców na emigracji, którzy, np. w 2004 roku stworzyli i zgłosili do opatentowania wynalazek (co wynika z dokumentacji patentowej), mogą znajdować się osoby, które wyemigrowały z Polski we wcześniejszych okresach. Ponadto, dokumenty patentowe pozwalają jedynie na określenie obywatelstwa wynalazcy, co oznacza, że nie wszyscy, np. wynalazcy legitymujący się polskim obywatelstwem w jakimś kraju muszą być migrantami (mogli urodzić się w tym kraju w polskiej rodzinie) lub też niektórzy wynalazcy są imigrantami pochodzącymi z Polski, ale otrzymali już obywatelstwo swojego kraju przeznaczenia, przez co nie będą wychwytywani jako polscy imigranci.

\section{Wielkość i kierunki przepływów migracyjnych Polaków}

Na podstawie chyba najbardziej rozbudowanej i najbardziej szczegółowej bazy danych dotyczącej przepływów migracyjnych na świecie, opracowanej przez 
OECD, można stwierdzić, że Polacy najchętniej emigrują do Niemiec, Stanów Zjednoczonych oraz Wielkiej Brytanii. O ile jednak główny korytarz polskiej emigracji jako całości prowadzi do Niemiec, o tyle wysoko wykształcone jednostki preferują Wielką Brytanię, która jest również ulubionym miejscem emigracji polskich kobiet (tab. 1). Co ciekawe, w odniesieniu zarówno do całkowitej emigracji, jak i emigracji osób z wysokim kapitałem ludzkim, od 2000 roku wzrasta udział emigrujących Polaków do Wielkiej Brytanii, natomiast preferencje odnośnie do Stanów Zjednoczonych i Niemiec rozkładają się odmiennie. Dla polskiej emigracji jako całości Stany Zjednoczone i Niemcy stają się coraz mniej popularnymi krajami docelowymi, podczas gdy wysoko wykształceni emigranci coraz chętniej osiedlają się właśnie w tych krajach. Natomiast kobiety, choć najczęściej decydują się na pobyt w Wielkiej Brytanii, to jednak na przestrzeni czasu ich udział w tym kraju się zmniejsza, podobnie jak w Stanach Zjednoczonych, podczas gdy zwiększa się w Niemczech.

Tabela 1. Emigracja Polaków w latach 2000-2011

\begin{tabular}{|l|c|c|c|}
\cline { 2 - 4 } \multicolumn{1}{c|}{} & $2000 / 2001$ & $2005 / 2006$ & $2010 / 2011$ \\
\hline Emigracja (tys.) & 2264,4 & 2791,9 & 3285,4 \\
\hline Wysoko wykształcona emigracja (tys.) & 467,2 & 728,7 & 1007,5 \\
\hline $\begin{array}{l}\text { Udział wysoko wykształconej emigracji w emigracji } \\
\text { ogółem (\%) }\end{array}$ & 21,9 & 26,1 & 30,6 \\
\hline Stopa wysoko wykształconej emigracji (\%) & 13,0 & 15,5 & 17,3 \\
\hline Stopa wysoko wykształconej emigracji kobiet (\%) & 12,6 & 15,2 & 15,9 \\
\hline & DE: 48,0 & DE: 45,0 & DE: 32,9 \\
Główne kierunki emigracji (\%) & $\begin{array}{l}\text { US: } 21,5 \\
\text { GB: } 2,8\end{array}$ & GS: 16,8 & GS: 13,8 \\
\hline & $\begin{array}{l}\text { DE: } 16,5 \\
\text { US: } 26,4\end{array}$ & $\begin{array}{c}\text { DE: } 16,9 \\
\text { US: } 36,2\end{array}$ \\
Główne kierunki wysoko wykształconej emigracji (\%) & GB: 37,8 & GB: 42,1 & \\
\hline \multirow{2yyy}{*}{ Główne kierunki emigracji kobiet (\%) } & DE: 12,8 & DE: 13,5 & \\
& US: 10,0 & US: 8,4 & \\
GB: 62,0 & GB: 28,3 & \\
\hline
\end{tabular}

Źródło: opracowanie na podstawie Arslan, Dumont, Kone i in. (2014); Dumont, Spielvogel, Widmaier (2010); Widmaier, Dumont (2011); OECD.Stat.

Jak wskazują również dane z bazy OECD, od 2000 roku wzrasta zarówno sama liczba opuszczających Polskę rodaków, jak i liczba najbardziej wykształconych Polaków. Co więcej, wzrasta także odsetek osób z wykształceniem wyższym 
w całkowitej emigracji Polaków oraz stopa wysoko wykształconej polskiej emigracji (udział wysoko wykształconych emigrujących jednostek w ogólnej liczbie wysoko wykształconych Polaków), a także stopa emigracji wysoko wykwalifikowanych polskich kobiet (udział wysoko wykształconych emigrujących polskich kobiet w liczbie wysoko wykształconych polskich kobiet ogółem). Warto w tym miejscu także zaznaczyć, że odsetek osób z najwyższym kapitałem ludzkim w ogólnej liczbie emigrantów, a także stopa wysoko wykształconej emigracji w Polsce są dość wysokie, zwłaszcza w porównaniu do innych, głównych gospodarek pochodzenia wysoko wykształconych jednostek, np. Indii, Chin, Meksyku, Niemiec, Rosji czy Francji (Arslan, Dumont, Kone i in., 2014; Dumont, Spielvogel, Widmaier, 2010; Widmaier, Dumont, 2011).

Po akcesji do UE, zwiększyły się nie tylko strumienie odpływów Polaków z kraju, ale również sama liczba Polaków przebywających za granicą - co sugeruje, że jedynie nieliczni Polacy decydują się na powrót do kraju - choć w niektórych krajach, np. w Stanach Zjednoczonych, liczba naszych rodaków obniżyła się (tab. 2).

Tabela 2. Liczba Polaków przebywających za granicą w latach 2004-2012, według kraju urodzenia (tys.)

\begin{tabular}{|l|c|r|r|r|r|r|r|r|r|}
\hline Kraj pobytu & 2004 & 2005 & 2006 & 2007 & 2008 & 2009 & 2010 & 2011 & 2012 \\
\hline Ogółem & 828,8 & 1626,9 & 2176,0 & 1999,0 & 2215,9 & 2829,1 & 2922,7 & 3267,7 & 2996,0 \\
\hline UE-15 & 189,9 & 1035,8 & 1366,9 & 1351,0 & 1556,8 & 2214,3 & 2249,2 & 2425,9 & 2335,0 \\
\hline US & 490,1 & 449,1 & 488,6 & 487,6 & 490,2 & 437,5 & 470,0 & 452,2 & 436,5 \\
\hline
\end{tabular}

Źródło: OECD.Stat.

\section{Wielkość i kierunki migracji polskich wynalazców. Wyniki badań}

Analiza aplikacji patentowych PCT wykazała, że w latach 2004-2012 łącznie w 46 państwach objętych analizą przebywało 962 wynalazców PCT pochodzenia polskiego, przy czym ich emigracja ograniczała się głównie do Europy, w której przebywało łącznie 581 twórców rozwiązań technicznych, oraz Ameryki Północnej, która przyciągnęła 363 polskich wynalazców. Gospodarki Azji, Ameryki Południowej i Australii były natomiast dość rzadko wybierane przez polskich wynalazców jako miejsce docelowej rezydencji (tab. 3, rys. 1). 
Rysunek 1. Udział polskich wynalazców PCT w poszczególnych krajach w całkowitej liczbie polskich mobilnych wynalazców PCT (lata 2004-2012)

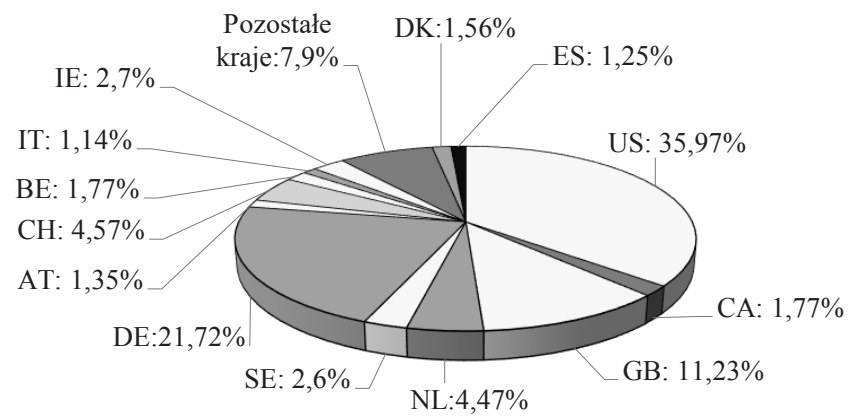

Źródło: opracowanie i obliczenia własne na podstawie zasobów wiedzy WIPO.

Tabela 3. Liczba polskich wynalazców PCT przebywających w wybranych krajach w latach 2004-2012

\begin{tabular}{|l|c|c|c|c|c|c|c|c|c|c|}
\hline \multicolumn{1}{|c|}{ Państwo } & 2004 & 2005 & 2006 & 2007 & 2008 & 2009 & 2010 & 2011 & 2012 & Lącznie* \\
\hline \multicolumn{1}{|c|}{1} & 2 & 3 & 4 & 5 & 6 & 7 & 8 & 9 & 10 & 11 \\
\hline Albania: AL. & 0 & 0 & 0 & 0 & 0 & 0 & 0 & 0 & 0 & 0 \\
\hline Argentyna: AR & 0 & 0 & 0 & 0 & 0 & 1 & 0 & 0 & 0 & 1 \\
\hline Australia: AU & 0 & 0 & 1 & 1 & 0 & 0 & 3 & 0 & 0 & 5 \\
\hline Austria: AT & 1 & 2 & 2 & 3 & 2 & 2 & 4 & 6 & 6 & 13 \\
\hline Belgia: BE & 3 & 1 & 4 & 5 & 6 & 4 & 3 & 3 & 2 & 17 \\
\hline Białoruś: BY & 0 & 0 & 0 & 0 & 0 & 0 & 0 & 0 & 0 & 0 \\
\hline Bośnia i Hercegowina: BA & 0 & 0 & 0 & 0 & 0 & 0 & 0 & 0 & 0 & 0 \\
\hline Brazylia: BR & 0 & 0 & 0 & 0 & 0 & 0 & 1 & 0 & 0 & 1 \\
\hline Bułgaria: BG & 0 & 0 & 0 & 0 & 0 & 0 & 0 & 0 & 1 & 1 \\
\hline Chile: CL & 0 & 0 & 0 & 0 & 0 & 0 & 0 & 0 & 0 & 0 \\
\hline Chiny: CN & 0 & 0 & 0 & 0 & 0 & 0 & 1 & 0 & 0 & 1 \\
\hline Chorwacja: HR & 0 & 0 & 0 & 4 & 0 & 0 & 0 & 0 & 0 & 4 \\
\hline Czarnogóra: ME & 0 & 0 & 0 & 0 & 0 & 0 & 0 & 0 & 0 & 0 \\
\hline Czechy: CZ & 0 & 0 & 0 & 1 & 1 & 0 & 0 & 0 & 0 & 2 \\
\hline Dania: DK & 1 & 2 & 6 & 2 & 2 & 1 & 1 & 4 & 5 & 15 \\
\hline Estonia: EE & 0 & 0 & 0 & 0 & 0 & 0 & 0 & 0 & 0 & 0 \\
\hline Finlandia: FI & 1 & 0 & 0 & 2 & 3 & 4 & 4 & 4 & 1 & 10 \\
\hline Francja: FR & 8 & 9 & 11 & 7 & 7 & 6 & 6 & 7 & 7 & 35 \\
\hline Grecja: GR & 0 & 0 & 0 & 0 & 0 & 0 & 0 & 0 & 0 & 0 \\
\hline Hiszpania: ES & 0 & 0 & 1 & 1 & 3 & 1 & 4 & 3 & 3 & 12 \\
\hline
\end{tabular}




\begin{tabular}{|l|r|r|r|r|r|r|r|r|r|r|}
\hline & 2 & 3 & 4 & 5 & 6 & 7 & 8 & 9 & 10 & 11 \\
\hline Holandia: NL & 6 & 10 & 11 & 9 & 9 & 11 & 11 & 9 & 8 & 43 \\
\hline Indie: IN & 0 & 0 & 0 & 0 & 0 & 0 & 0 & 0 & 0 & 0 \\
\hline Irlandia: IE & 2 & 1 & 0 & 2 & 4 & 8 & 5 & 9 & 4 & 26 \\
\hline Japonia: JP & 2 & 3 & 2 & 4 & 2 & 4 & 2 & 2 & 2 & 9 \\
\hline Kanada: CA & 1 & 2 & 3 & 5 & 3 & 5 & 3 & 6 & 3 & 17 \\
\hline Litwa: LT & 0 & 0 & 0 & 0 & 0 & 0 & 0 & 0 & 0 & 0 \\
\hline Luksemburg: LU & 1 & 1 & 1 & 1 & 1 & 0 & 0 & 0 & 0 & 1 \\
\hline Lotwa: LV & 0 & 0 & 0 & 0 & 0 & 0 & 0 & 0 & 0 & 0 \\
\hline Macedonia: MK & 0 & 0 & 0 & 0 & 0 & 0 & 0 & 0 & 0 & 0 \\
\hline Mołdawia: MD & 0 & 0 & 0 & 0 & 0 & 0 & 0 & 0 & 0 & 0 \\
\hline Niemcy: DE & 35 & 34 & 41 & 41 & 53 & 58 & 58 & 49 & 45 & 209 \\
\hline Norwegia: NO & 0 & 0 & 0 & 0 & 0 & 1 & 1 & 3 & 4 & 6 \\
\hline Republika Korei: KR & 0 & 0 & 0 & 0 & 0 & 0 & 0 & 0 & 0 & 0 \\
\hline Rosja: RU & 0 & 0 & 0 & 0 & 0 & 0 & 0 & 0 & 0 & 0 \\
\hline Rumunia: RO & 0 & 0 & 0 & 0 & 0 & 0 & 0 & 0 & 0 & 0 \\
\hline Serbia: XS & 0 & 0 & 0 & 0 & 0 & 0 & 0 & 0 & 0 & 0 \\
\hline Słowacja: SK & 0 & 0 & 0 & 0 & 0 & 0 & 0 & 0 & 0 & 0 \\
\hline Słowenia: SI & 0 & 0 & 0 & 0 & 0 & 0 & 0 & 0 & 0 & 0 \\
\hline Stany Zjednoczone: US & 45 & 69 & 87 & 92 & 108 & 97 & 77 & 79 & 46 & 346 \\
\hline Szwajcaria: CH & 6 & 9 & 8 & 9 & 13 & 10 & 8 & 7 & 8 & 44 \\
\hline Szwecja: SE & 6 & 7 & 5 & 6 & 5 & 7 & 9 & 10 & 3 & 25 \\
\hline Turcja: TR & 0 & 0 & 0 & 0 & 0 & 0 & 0 & 0 & 0 & 0 \\
\hline Ukraina: UA & 0 & 0 & 0 & 0 & 0 & 0 & 0 & 0 & 0 & 0 \\
\hline Węgry: HU & 0 & 0 & 0 & 0 & 0 & 0 & 0 & 0 & 0 & 0 \\
\hline Wlk. Brytania; GB & 10 & 12 & 17 & 16 & 25 & 27 & 26 & 25 & 31 & 108 \\
\hline Włochy: IT & 0 & 1 & 1 & 1 & 3 & 2 & 0 & 1 & 2 & 11 \\
\hline Suma & 128 & 163 & 201 & 212 & 250 & 249 & 227 & 227 & 181 & 962 \\
\hline
\end{tabular}

* Łączna liczba wynalazców za okres 2004-2012 nie sumuje się z liczbą wynalazców w poszczególnych latach. Jeden wynalazca może bowiem przebywać w danym kraju przez kilka lat.

Źródło: opracowanie i obliczenia własne na podstawie zasobów wiedzy WIPO.

Spośród państw europejskich głównym kierunkiem migracyjnym polskich wynalazców w badanym okresie były Niemcy $(21,72 \%$ polskich wynalazców spośród ogółu mobilnych polskich wynalazców wybierało ten kraj), Wielka Brytania (11,23\%), Szwajcaria (4,57\%) i Holandia (4,47\%); z Ameryki Północnej - Stany Zjednoczone (35,97\%), zaś Azji - Japonia (0,93\%) (rys. 1). Należy jednak podkreślić, że znaczna część z objętych badaniem państw (21) w ogóle nie doświadcza napływu wynalazców z Polski. Należą do nich przede wszystkim kraje Europy 
Środkowo-Wschodniej, byłego ZSSR, Bałkany, a także kraje azjatyckie. Ponadto, w wielu państwach obecność wynalazców z Polski jest incydentalna.

Analiza wykazała także, że liczba Polaków podejmujących za granicą wysiłek twórczy nie rozkładała się równomiernie na przestrzeni dziewięciu lat objętych analizą, początkowo wykazując tendencję rosnącą, a następnie wyraźnie malejącą. Dotyczy to zarówno populacji polskich emigrantów-wynalazców jako całości, jak i tych przebywających w Europie i Ameryce Północnej (rys. 2). Trend ten jest szczególnie widoczny w Ameryce Północnej, w której już od 2008 roku znacznie obniża się liczba przebywających tam polskich wynalazców, de facto w 2012 roku osiągając poziom z 2004 roku. W Europie natomiast spadek w liczbie wynalazców z Polski jest widoczny od 2009 roku, przy czym jest on zdecydowanie mniejszy niż ma to miejsce w odniesieniu do Ameryki Północnej.

Rysunek 2. Geograficzny rozkład polskich wynalazców PCT w latach 2004-2012

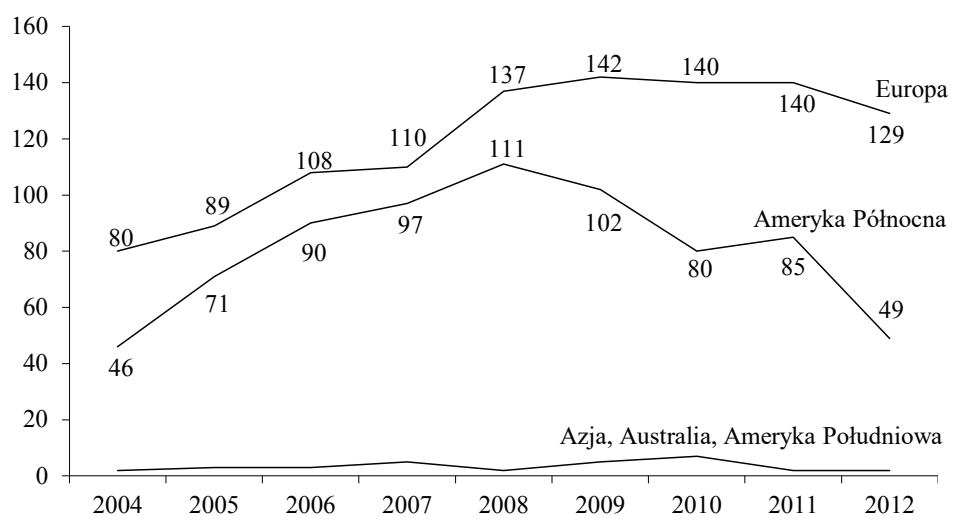

Źródło: opracowanie i obliczenia własne na podstawie zasobów wiedzy WIPO.

Jeśli chodzi o płeć opuszczających Polskę wynalazców, to aż 72,87\% z nich stanowią mężczyźni, a jedynie 27,13\% kobiety, najliczniej przebywające w Stanach Zjednoczonych, Niemczech i Wielkiej Brytanii. W ujęciu względnym zaś (z wyłączeniem państw, w których udział wynalazców z Polski jest znikomy), panie najliczniej są reprezentowane w Holandii (39,53\% wszystkich polskich wynalazców), Francji (37,14\%), Stanach Zjednoczonych (27,46\%), Szwajcarii $(25,0 \%)$ i Niemczech $(22,97 \%)$. Natomiast najmniejszy udział kobiet w łącznej liczbie polskich 
wynalazców na emigracji można zaobserwować w Irlandii (19,23\%) oraz Szwecji $(20,0 \%)$.

\section{Podsumowanie}

Niezmiennie od wielu lat najchętniej wybieranymi państwami przez polską emigrację są Niemcy, Wielka Brytania i Stany Zjednoczone. O ile jednak dla całości opuszczających nasz kraj rodaków głównym kierunkiem migracji są Niemcy, o tyle Polacy legitymujący się osiągniętym trzecim stopniem edukacji preferują Wielką Brytanię, natomiast polscy wynalazcy - Stany Zjednoczone, w których w latach 2004-2012 przebywało prawie 36\% wszystkich mobilnych polskich wynalazców. Oznacza to, że ścieżki migracyjne Polaków różnią się w zależności od poziomu ich wykształcenia i posiadanych umiejętności. Ogólnie, im bardziej wykwalifikowani Polacy, tym większe prawdopodobieństwo, że osiedlą się w Stanach Zjednoczonych, ci z trochę mniejszymi umiejętnościami w Wielkiej Brytanii, a pozostali - w Niemczech. Jeśli natomiast chodzi o preferencje emigrujących polskich kobiet-wynalazców dotyczące geograficznych kierunków migracji, to ogólnie odzwierciedlają one tendencje całości, tzn. podobnie jak polscy wynalazcy łącznie, panie najchętniej emigrują do Stanów Zjednoczonych, następnie do Niemiec, a w dalszej kolejności do Wielkiej Brytanii.

Poszczególne grupy polskich emigrantów mają odmienne preferencje nie tylko w odniesieniu do kierunków docelowej migracji, również trend w kształtowaniu się ich liczby w poszczególnych rejonach świata jest różny. O ile liczba przebywających za granicą Polaków ogółem wzrasta z roku na rok, o tyle trend w liczbie polskich wynalazców na obczyźnie jest malejący, szczególnie widoczny od 2008 roku.

Obraz, jaki wyłania się na podstawie przytoczonych wyników, pokazuje wprawdzie, że Polska „straciła” wielu, bo w latach 2004-2012 łącznie aż 962, wynalazców, jednak daje także podstawę do osłabienia pewnych lęków związanych z emigracją wykształconych Polaków. Wyniki pokazują bowiem, że mimo coraz większej otwartości gospodarek narodowych i coraz większych możliwości osiedlania się i podejmowania pracy za granicą, migracja netto najcenniejszego kapitału ludzkiego wykazuje trend malejący.

Przytoczone wyniki świadczą również o tym, że migracja ludności jest zjawiskiem złożonym i że wszelkie uogólnienia dotyczące mobilnej części obywateli 
mogą być dalekie od prawdy. Zupełnie inne preferencje mają bowiem osoby, które bez jakiegokolwiek wykształcenia decydują się opuścić swój kraj niż te charakteryzujące się wysokim kapitałem ludzkim. Podobnie odmienne są wzorce zachowań wśród różnych zbiorów jednostek w obrębie jednej grupy mobilnych osób z tymi samymi osiągnięciami edukacyjnymi. Dlatego wnioski z badań, w których efekty migracji - czy to dla kraju źródłowego, czy przeznaczenia - rozpatrywane są w odniesieniu do wąskich, w miarę homogenicznych grup migrantów, mają większy walor poznawczy i aplikacyjny.

\section{Literatura}

Agrawal, A., Kapur, D., McHale, J. (2008). Brain Drain or Brain Bank? The Impact of Skilled Emigration on Poor-country Innovation. NBER Working Paper Series, 14592.

Arslan, C., Dumont, J-C., Kone, Z., Moullan, Y., Ozden, C., Parsons, Ch., Xenogiani, T. (2014). A New Profile of Migrants in the Aftermath of the Recent Economic Crisis. OECD Social, Employment and Migration Working Papers, 160. OECD Publishing. Pobrano z: http://dx.doi.org/10.1787/5jxt2t3nnjr5-en (25.02.2017).

Azoulay, P., Graff Zivin, J.S., Sampat, B.N. (2011). The Diffusion of Scientific Knowledge across Time and Space: Evidence from Professional Transitions for the Superstars of Medicine. NBER Working Paper Series, 16683.

Breschi, S., Lissoni, F., Miguelez, E. (2015). Foreign Inventors in the US: Testing for Diaspora and Brain Gain Effects. GREThA Working Paper, 2015-25.

Breschi, S., Lissoni, F., Tarasconi, G. (2014). Inventor Data for Research on Migration and Innovation: A Survey and Pilot. WIPO Working Paper, 17.

Docquier, F., Rapoport, H. (2012). Globalization, Brain Drain, and Development. Journal of Economic Literature, 50, 681-730.

Dumont, J-C., Spielvogel, G., Widmaier, S. (2010). International Migrants in Developed, Emerging and Developing Countries: An Extended Profile. OECD Social, Employment and Migration Working Papers, 114. Pobrano z: www.oecd.org/els/workingpapers (25.02.2017).

Freeman, R.B. (2010). Globalization of Scientific and Engineering Talent: International Mobility of Students, Workers, and Ideas and the World Economy. Economicc of Innovation and New Technology, 19, 393-406.

Miguelez, E., Fink, C. (2013). Measuring the International Mobility of Inventors: A New Database. WIPO Working Paper, 8. 
OECD (2013). World Migration in Figures 2013. Pobrano z: http://www.oecd.org/els/mig/ dioc.htm (21.02.2017).

OECD (2015). Connecting with Emigrants. A Global Profile of Diasporas 2015. Paris: OECD Publishing.

OECD.Stat. Pobrano z: http://stats.oecd.org/\# (6.03.2017).

Widmaier, S., Dumont, J-C. (2011). Are Recent Immigrants Different? A New Profile of Immigrants in the OECD Based on DIOC 2005/06. OECD Social, Employment and Migration Working Papers No. 126, Directorate for Employment, Labour and Social Affairs. Paris: OECD Publishing. Pobrano z: http://dx.doi.org/10.1787/5kg3ml17nps4-en (25.02.2017).

\title{
THE DIRECTIONS OF POST-ACCESSION EMIGRATION OF POLISH INVENTORS
}

\begin{abstract}
The purpose of the paper is to determine the volume and geographical directions of emigration of Polish inventors in years 2004-2012. An analysis of patent applications filed in years 2004-2012 under the international procedure by residents from Europe, North America, Australia as well as the largest economies of Asia and South America has shown that in years 2004-2012 a total of 962 inventors of Polish origin lived in 46 countries covered by the analysis. Their main direction of migration was Europe (mainly Germany, the UK, Switzerland and the Netherlands), where a total of 581 authors of technical inventions lived and North America (mainly the US), which attracted 363 Polish inventors. In Asia, South America and Australia, the presence of Polish inventors was incidental.
\end{abstract}

Translated by Rafat Krawczyk

Keywords: human capital migration, inventors, PCT patent applications, Poland JEL code: F22 
